\title{
Bone Marrow Carcinosis and Disseminated Tumour Cells
}

\author{
Muireann T. Kelleher ${ }^{\mathrm{a}, \mathrm{b}} \quad$ Anne Kendall ${ }^{\mathrm{a}}$ Simon Chowdhury ${ }^{\mathrm{a}}$ \\ a Department of Medical Oncology, Guy's and St Thomas NHS Foundation Trust, \\ ${ }^{\mathrm{b}}$ Richard Dimbleby Department of Cancer Research, Guy's Medical School Campus, Kings College London, UK
}

The occurrence of overwhelming bone marrow infiltration by solid tumour cells is rarely reported. Despite the paucity of published data, this is not rare clinically and is often seen as a late-stage event. The article by Flörcken and colleagues in the October 2009 issue of OnKOLOGIE is indeed relevant [1]. The authors state that where bone marrow carcinosis has been reported it is usually associated with a large burden of disease, rapid progression and death. Yet there have been positive reports of long-term disease control in bone marrow carcinosis caused by solid tumours [2,3]. The 63-year old female patient described by Flörcken and colleagues died within 5 months of initial presentation [1]. The diagnosis of metastatic renal cell cancer was confirmed after investigation of thrombocytopenia. This is an unusual complication of renal cell cancer and to our knowledge the first reported case.

Unexplained or progressive cytopenias in cancer patients should raise the possibility of bone marrow carcinosis. For patients without a cancer diagnosis, though other causes of bone marrow failure should be investigated, early bone marrow biopsy may help to diagnose the primary site of malignancy. Nuclear medicine bone scan and bone marrow biopsy are required to establish the diagnosis of disseminated carcinomatosis of the marrow. Bone scintigraphy commonly demonstrates a super-scan of malignancy. Bone marrow trephine generally exhibits the highest yield for detecting metastatic disease, as aspiration may prove unsuccessful due to fibrosis [4]. The marrow serves as a reservoir of tumour cells with the potential to metastasise. The physical burden of tumour cells within the bone marrow may eventually interfere with haematopoiesis, haemostasis and immune responses. Bone marrow carcinosis then becomes clinically significant, often compounded by myelosuppressive cytotoxics.

The incidence of bone marrow carcinosis was investigated in 380 breast cancer patients at the time of first recurrence. 87 patients $(23 \%)$ had sufficient tumour cells in the bone marrow to be deemed bone marrow carcinosis. Matrix bone metastases were demonstrated in $78 \%$ of patients with bone marrow carcinosis versus only $16 \%$ of the patients without bone marrow carcinosis. Heavy tumour infiltration of the bone marrow was associated with multiple bone lesions with histopathologic evidence of bone destruction [5]. This study provided evidence that the primary soil of metastatic bone disease in breast cancer is the bone marrow. Bone metastases are the result of invasion and destruction of bone tissue matrix mostly by tumour cells from within the marrow cavity.

Intuitively, if bone marrow carcinosis heralds progression, the presence of even a small number of metastatic cells within the bone marrow should correlate with poor outcome. Disseminated carcinoma cells (DTCs) are clearly detectable in the bone marrow very early in the diagnosis of many solid tumours [6]. DTCs are distinct from frank bone marrow carcinosis as they are not associated with marrow dysfunction. However, clearly both exist on a continuum. Cells appear to disseminate from early primary lesions and then acquire additional genetic defects. Gene expression patterns of DTCs are often strikingly similar to the cells from the primary tumour [6]. The bone marrow may form the preferred reservoir for metastatic tumour cells, from where they re-circulate to distant organs where better growth conditions exist. The presence of DTCs in the bone marrow of primary breast cancer patients is an independent prognostic indicator of relapse, correlating with the appearance of bone metastases and with the occurrence of overt metastasis at other sites [7]. Significant correlations have been shown between DTCs in the bone marrow and metastatic relapse [8].

Animal models indicate that a significant proportion of DTCs remain dormant or perish, never developing into overt metastases [9]. Dormancy can be defined as slow-growing tumours that appear after long latency periods, quiescent tumours with no growth at all, or tumours that are in prolifera-

\section{KARGER}

Fax +497614520714

Information@Karger.de

www.karger.com (c) 2010 S. Karger GmbH, Freiburg

Accessible online at:

www.karger.com/onk
Simon Chowdhury, MD

Department of Medical OncologyGuy's and St Thomas

NHS Foundation Trust

London SE1 9RT, United Kingdom

simon.chowdhury@gstt.nhs.uk 
tive and apoptotic equilibrium. Cancer dormancy represents a potentially useful therapeutic goal [10]. An intriguing issue related to the apparent dormant, non-proliferating nature of many DTCs is the trigger that initiates proliferation. HER2 appears to define an aggressive subset of DTCs associated with poor prognosis in breast cancer [11] and expression of urokinase-type plasminogen activator receptor (UPAR) has been correlated to metastatic relapse in gastric cancer [12], suggesting that signalling mediated by HER2 and UPAR might be important for the transition of DTCs from a dormant stage to an active growth phase [13]. In addition adaptive immunity has been observed to play an important role in dormancy [14]. Tumour equilibrium constitutes part of what can be described as the 'immuno-editing' process. In mouse models of dormant tumours (equilibrium between cell growth and cell death) depletion of CD4 and CD8 cells, combined with inhibition of interferon- $\gamma$, initiated progressive growth [14].

Despite their strong prognostic significance, DTCs or CTCs (circulating tumour cells in the peripheral blood) will only have a convincing clinical application if they can be reliably measured and are proven to be a surrogate marker for treatment efficacy. To date the ASCO recommendations are that detection of DTCs, and CTCs have yet to demonstrate sufficient evidence to support routine use in clinical practice [15].

The presence of malignant tumour cells within the bone marrow offers both challenges and opportunities to clinicians. There is growing evidence that bisphosphonates, used as standard treatment for proven bone metastases to reduce skeletal events, can impact on the development of distant non-osseous visceral disease [16]. Murine models have demonstrated that treatment with zoledronic acid resulted in a reduction in the number of bone, liver and lung metastases and increased overall survival [17]. In contradiction to the conventional theory that metastatic invasive tumour cell dissemination is a late event, animal models have indicated that premalignant lesions can disseminate early and may even become evident as metastases before an invasive primary has become apparent [18]. It is postulated that bisphosphonates lead to the creation of an unfavourable bone marrow stromal 'soil' whereby dormant DTCs are eradicated interrupting their development into measurable clinical disease. Such concepts have been used to support the trials of adjuvant bisphosphonates with conventional treatment in early solid tumours.

The Austrian Breast and Colorectal Cancer Study Group ABCSG-12 trial [19] is the first clinical study to report an improvement in long-term outcome in early-stage cancer by the addition of a bisphosphonate. Over 1,800 premenopausal women with stage I/II breast cancer were treated by biochemical ovarian suppression with an initial randomisation to tamoxifen or an aromatase inhibitor, followed by a subsequent randomisation to zoledronic acid every 6 months for 3 years or no additional therapy. The addition of zoledronic acid resulted in a significant reduction in the risk of a DFS event (hazard ratio $0.64 ; 95 \%$ CI $0.46-0.91 \mathrm{P}=0.01$ ). Zoledronic acid seemed to reduce all categories of DFS events including distant non-osseous relapses, locoregional recurrences and contralateral primary breast cancers. In addition preliminary data from the neoadjuvant run-in portion of the AZURE (Adjuvant Zoledronic Acid reduce Recurrence) trial has shown a higher rate of pathological complete response compared to chemotherapy alone but long term survival and distant metastasis data are keenly awaited [20].

In this era of targeted oncological therapy, cytotoxic chemotherapy is no longer the only available treatment option. For advanced bone marrow carcinosis rapid disease control is required and this may be best achieved with chemotherapy and bisphosphonates with or without targeted agents. This obviously will depend on the chemosensitivity of the disease and dosing will be dependent on the degree of marrow dysfunction. Most clinical trials do not routinely exclude patients on the basis of bone marrow carcinosis, however the requirement of 'adequate' bone marrow function prior to therapy excludes many such patients. It would be unrealistic to consider designing a clinical trial specifically to address the best treatment modality for bone marrow carcinosis, so data will remain scarce. However case series and case reports such as this one will continue to increase our knowledge of this important area.

\section{Conflict of Interest}

Dr. Kelleher and Dr. Kendall have no disclosures; Dr. Chowdhury is a member of advisory boards for Novartis, Sanofi and GSK.

\section{References}

1 Flörcken A, Loew A, Koch M, et al.: Severe thrombocytopenia in a patient with metastatic renal cell carcinoma. Onkologie 2009;32:670-672.

2 Bjelic-Radisic V, Stoger H, Winter R, et al.: Longterm control of bone marrow carcinosis and severe thrombocytopenia with standard-dose chemotherapy in a breast cancer patient: a case report. Anticancer Res 2006:26:1627-1630.

3 Baeksgaard L, Sorensen JB: Acute tumor lysis syndrome in solid tumors - a case report and review of the literature. Cancer Chemother Pharmacol 2003; 51:187-192.
4 Fend F, Tzankov A, Bink K, et al.: Modern techniques for the diagnostic evaluation of the trephine bone marrow biopsy: methodological aspects and applications. Prog Histochem Cytochem 2008;42: 203-252.

5 Kamby C, Guldhammer B, Vejborg I, et al.: The presence of tumor cells in bone marrow at the time of first recurrence of breast cancer. Cancer 1987; 60:1306-1312.

6 Pantel K, Brakenhoff RH: Dissecting the metastatic cascade. Nat Rev Cancer 2004;4:448-456.
7 Braun S, Vogl FD, Schneitter A, et al.: Disseminated tumor cells: are they ready for clinical use? Breast 2007;16 Suppl 2:S51-54.

8 Vincent-Salomon A, Bidard FC, Pierga JY: Bone marrow micrometastasis in breast cancer: review of detection methods, prognostic impact and biological issues. J Clin Pathol 2008;61:570-576.

9 Chambers AF, Groom AC, MacDonald IC: Dissemination and growth of cancer cells in metastatic sites. Nat Rev Cancer 2002;2:563-572.

10 Aguirre-Ghiso JA: Models, mechanisms and clinical evidence for cancer dormancy. Nat Rev Cancer 2007;7:834-846. 
11 Braun S, Schlimok G, Heumos I, et al.: ErbB2 overexpression on occult metastatic cells in bone marrow predicts poor clinical outcome of stage I-III breast cancer patients. Cancer Res 2001;61:1890-1895.

$\checkmark 12$ Heiss MM, Simon EH, Beyer BC, et al.: Minimal residual disease in gastric cancer: evidence of an independent prognostic relevance of urokinase receptor expression by disseminated tumor cells in the bone marrow. J Clin Oncol 2002;20:2005-2016.

13 Pantel K, Brakenhoff RH, Brandt B: Detection, clinical relevance and specific biological properties of disseminating tumour cells. Nat Rev Cancer 2008;8:329340.

14 Koebel CM, Vermi W, Swann JB, et al.: Adaptive immunity maintains occult cancer in an equilibrium state. Nature 2007;450:903-907.

15 Harris L, Fritsche H, Mennel R, et al.: American Society of Clinical Oncology 2007 update of recommendations for the use of tumor markers in breast cancer. J Clin Oncol 2007;25:5287-5312.

16 Diel IJ, Solomayer EF, Costa SD, et al.: Reduction in new metastases in breast cancer with adjuvant clodronate treatment. N Engl J Med 1998;339:357-363.

17 Hiraga T, Williams PJ, Mundy GR, Yoneda T: The bisphosphonate ibandronate promotes apoptosis in MDA-MB-231 human breast cancer cells in bone metastases. Cancer Res 2001;61:4418-4424.

18 Husemann Y, Geigl JB, Schubert F, et al.: Systemic spread is an early step in breast cancer. Cancer Cell 2008;13:58-68.

19 Gnant M, Mlineritsch B, Schippinger W, et al.: Endocrine therapy plus zoledronic acid in premenopausal breast cancer. N Engl J Med 2009;360:679-691.

20 Winter MC, Coleman RE: Bisphosphonates in breast cancer: teaching an old dog new tricks. Curr Opin Oncol 2009;21:499-506.

\section{Impressum}

Die Zeitschrift erscheint monatlich; pro Jahr erscheint 1 Band zu je 12 Heften. Mitglieder der Deutschen Gesellschaft für Hämatologie und Onkologie erhalten die Zeitschrift im Rahmen ihrer Mitgliedschaft. Der Bezug ist im Rahmen des Mitgliedsbeitrags abgegolten. Bezugspreise für Jahrgang 33, 2010: PrintAbonnement EUR 245,-, Online-Abonnement EUR 245,-, Kombi-Abonnement Print/Online EUR 291,-, einschließlich MWSt., zuzüglich Postgebühren. Der Abonnementpreis ist im voraus zahlbar. Das Abonnement der Zeitschrift läuft weiter, wenn es nicht spätestens 4 Wochen vor Abschluss eines Bandes abbestellt wird. Abonnementbestellungen können bei jeder Buchhandlung oder direkt beim Verlag aufgegeben werden:

\author{
Deutschland: \\ S. Karger Verlag für Medizin und $\quad$ S. Karger AG \\ Naturwissenschaften $\mathrm{GmbH} \quad$ Allschwilerstr. 10 \\ Wilhelmstr. 20A \\ D-79098 Freiburg \\ Tel. +49761452070 \\ Postfach \\ CH-4009 Basel \\ Fax +497614520714 \\ Tel. +416130611 11 \\ Fax +41613061234 \\ E-mail Information@Karger.de \\ E-mail Karger@Karger.ch \\ Anzeigen: \\ S. Karger Verlag für Medizin und Naturwissenschaften GmbH \\ Wilhelmstr. 20A, D-79098 Freiburg, \\ Tel. +49761452070 \\ Gültig ist die Preisliste Nr. 20 vom 1. Januar 2010
}

Für den Inhalt außerhalb des redaktionellen Teiles (insbesondere Anzeigen, Industrieinformationen, Pressezitate und Kongressinformationen) übernehmen Schriftleitung, Beirat und Verlag keine Gewähr. Eine Markenbezeichnung kann warenzeichenrechtlich geschützt sein, auch wenn bei ihrer Verwendung in dieser Zeitschrift das Zeichen ${ }^{\circledR}$ oder ein anderer Hinweis auf etwa bestehende Schutzrechte fehlen sollte. Für Satzfehler, insbesondere bei Dosierungsangaben, wird keine Gewähr übernommen. Die Zeitschrift sowie alle in ihr enthaltenen einzelnen Beiträge und Abbildungen sind urheberrechtlich geschützt. Jede Verwertung, die nicht ausdrücklich vom Urheberrechtsgesetz zugelassen ist, bedarf der vorherigen Zustimmung des Verlags. Das gilt insbesondere für Vervielfältigungen, Bearbeitungen, Übersetzungen, Mikroverfilmungen und die Einspeicherung und Verarbeitung in elektronischen Systemen.

(C) Copyright 2010 by S. Karger

Verlag für Medizin und Naturwissenschaften $\mathrm{GmbH}$

Wilhelmstr. 20A, D-79098 Freiburg

Verlagsleitung und presserechtlich verantwortlich: Sibylle Hopf Produktionsleitung: Georg Brunner

Anzeigenleitung: Susanne Meister

Gesamtherstellung:

VVA/Konkordia GmbH, 76534 Baden-Baden

Das Medienunternehmen

Bibliographische Dienste
Biological Abstracts
Current Contents/Clinical Medicine
Excerpta Medica/EMBASE
Index Medicus/MEDLINE
Medical Documentation Service
Reference Update
Research Alert
Science Citation Index
SCISEARCH Database

Beilagenhinweis: Diese Ausgabe erscheint mit den Beilagen „Therapien der Zukunft" von Novartis Pharma GmbH, Nürnberg, und „Gyn-Telegramm 01/2010“ von AstraZeneca GmbH, Wedel.

\section{KARGER}

Fax +497614520714 Information@Karger.de www.karger.com
() 2010 S. Karger GmbH, Freiburg

Accessible online at:

www.karger.com/onk 